This is an electronic reprint of the original article. This reprint may differ from the original in pagination and typographic detail.

Author(s): Meriluoto, Taina

Title: 'The will to not be empowered (according to your rules)' : Resistance in Finnish participatory social policy

Year: $\quad 2019$

Version:

Please cite the original version:

Meriluoto, T. (2019). 'The will to not be empowered (according to your rules)' :

Resistance in Finnish participatory social policy. Critical Social Policy, 39(1), 87-107.

https://doi.org/10.1177/0261018318764322

All material supplied via JYX is protected by copyright and other intellectual property rights, and duplication or sale of all or part of any of the repository collections is not permitted, except that material may be duplicated by you for your research use or educational purposes in electronic or print form. You must obtain permission for any other use. Electronic or print copies may not be offered, whether for sale or otherwise to anyone who is not an authorised user. 
Author's original manuscript

The Version of Record of this manuscript will be published and made available in Critical Social Policy (2018)

Taina Meriluoto

$\mathrm{PhD}$ Candidate, Political Science

Department of Social Sciences and Philosophy

PL 35, 40014 University of Jyväskylä, Finland

$+358445239839$

taina.meriluoto@jyu.fi

\section{'The will to not be empowered (according to your rules)' - Resistance in Finnish participatory social policy}

Participation has increasingly become a means and an end for successful and 'empowering' social policy. Building on previous governmentality critiques of participatory initiatives, this article investigates practices of resistance in the context of Finnish participatory social policy. I adopt a Foucauldian counter-conducts approach as my lens to study critical speech as a form of resistance in initiatives that invite marginalised people as 'experts-by-experience' in social welfare organisations. I illustrate how practices of governing and resistance are intertwined and mutually dependent in a much subtler and more practical manner than allows the often-used analytical dichotomy between dominance and empowerment. As an example, I show how the projects' attempts to co-opt the participants' critical speech may also serve as the basis for their subversive self-making and means of 'being differently'.

Keywords: counter-conduct, experts-by-experience, governmental ethnography, parrhesia, participatory initiatives 


\section{Introduction}

The democratic capacity of the newly popular participatory arrangements is a muchdebated issue (e.g. Lee et al., 2015; Papadopoulos and Warin, 2007). Often, these critical analyses operate through a grid that labels the participatory initiatives as either truly empowering, i.e. 'giving power' to subordinate groups, or repressive in their manner of co-opting the participants' inputs to advance the administration's goals (Wilson and Beresford, 2000; Leppo and Perälä, 2009; cf. Prior, 2009).

These analyses tend to echo an understanding of power as a zero-sum game with someone 'holding it' and on rare occasions as 'giving it' to the participants (Baistow, 1994; Pease, 2002; e.g. Arnstein, 1969). This makes power and resistance appear as polar opposites instead of seeing them as being mutually dependent and a product of one another (see Death, 2010). Subsequently, the subtler, small-scale negotiations that entail subversive potential are easily overlooked (also Griggs et al., 2014).

In this article I adopt Death's counter-conducts approach (2016) as my lens by which to scrutinise the grassroots-level negotiations and 'ways of being differently' that the participatory projects' members employ. I study seven Finnish participatory initiatives that invite former service users to act as 'experts-by-experience' in social welfare organisations. These initiatives entail different practices geared towards defining and teaching 'appropriate ways' to formulate and share the participants' life stories so that they may be considered knowledge and subsequently recognised as valid input in decision-making. By focusing on the practices the participants use to resist these predefined ways of 'knowing oneself', I illustrate how practices of governing and resistance are intertwined and mutually dependent in a much subtler and more practical manner than allows the often used analytical dichotomy between dominance and 
empowerment. As an example, I show how the projects' attempts to co-opt the participants' critical speech may also serve as the basis for their subversive self-making and means of 'being differently'.

I will start by diving into the participatory wave of Finnish social policy and situate the projects developing expertise-by-experience among previous governmentality studies on participatory arrangements. Then, I will introduce Foucault's concepts of counter-conduct and parrhesia as my analytical tools. After presenting my data and my methodology of governmental ethnography, my analysis will focus on the instances where the projects' participants attempted to 'be differently'. I conclude by suggesting what possible further avenues for research might be opened up if power and resistance were understood as interwoven when investigating participatory practices.

\section{Experts-by-experience and other governable subjects}

The term 'expert-by-experience' was introduced into the Finnish context as an import, mainly from the UK (see Barnes, 2009a; Noorani, 2013). In early 2010, the concept was rapidly disseminated by mental health organisations to the social welfare and healthcare sector after The National Development Programme for Social Welfare and Health Care (Kaste) adopted the term as a symbol for involving and engaging social welfare clients (Rissanen, 2015). Nowadays, the term is used to refer to those former service users or social welfare clients who participate in various roles by drawing on their experiential knowledge. Their activities vary from being consultants and evaluators in service co-production, to lecturers, spokespeople and peer-supporters.

Expertise-by-experience is illustrative of a recent participatory trend in Finnish social policy that encourages social welfare organisations to 'activate' their clients (Leemann and Hämäläinen, 2016). As elsewhere, the rationales behind this will to 
activate, and its experienced outcomes, are diverse. Närhi and Kokkonen (2014) have shown how the participatory ethos merges democratic and consumerist rationales, which creates contradictory participant-roles for the service-users (also Meriluoto, 2018).

Furthermore, based on recent research indicating how many participatory initiatives have failed in their promise to amplify the service users' voice in the service system (Matthies et al., 2018; Meriluoto, 2017), Finnish researchers have also come to interpret welfare users' participation as a tool of governance, aimed primarily at producing more selfsustained citizens and building legitimation for decisions already made (Matthies, 2017; Meriluoto, 2016). Leemann and Hämäläinen (2016) even propose that a particularity of Finnish participatory schemes is their strong emphasis on the experiential aspect of participation. What counts most is that people feel included.

As a case in point, the aims of expertise-by-experience are manifold. It is perceived of as a means to co-produce services, to ensure 'knowledge-based decisionmaking' through the incorporation of experiential knowledge, to provide proof of upholding the participatory norm of good governance and to 'empower' the initiatives' participants (Cowden and Singh, 2007; Barnes, 2009a). Through increased participation, and most of all as a result of 'getting their voices heard', it is hoped that the projects' participants feel more included and in charge of the issues that are important to them (Barnes, 2009a; Lee et al., 2015; Martin, 2012a). Fundamentally, the experts'-byexperience role is presented as being to provide 'raw' and 'authentic' experiences to help in decision-making, service production and public discussion.

A particularity of the Finnish initiatives on expertise-by-experience is that they are all, as Warren (2009) would put it, 'governance-driven', which is in contrast to some user-initiated and user-led initiatives in the UK (Noorani, 2013). The projects' administration is largely in charge of sketching the aims, scope and practices of the 
projects and invites the participants to a predefined environment of action. Moreover, the projects not only choose their participants but also include various techniques, such as trainings and 'practice lectures', that steer the participants' discourse and way of being. These techniques operate very overtly on and through the participants' self-construction. The trainings are organised with the aim to 'reorganise the participants' life story', and the practice lectures teach participants 'the best' way of telling about their experiences to different publics (see Meriluoto, 2017). Subsequently, in these projects the practices steering the participants' self-construction are exceptionally tangible.

The governmentality literature has directed attention to these practices of selfmaking within participatory schemes, often criticising them for their tendency to curb rather than open up possibilities for being (Cruikshank, 1999; Polletta, 2014). Often, these analyses interpret the participants' position through a binary of empowerment or appropriation/co-optation (Baistow, 1994; e.g. Fox et al., 2005; Wilson and Beresford, 2000; cf. McKee and Cooper, 2008). In general terms, empowerment in participatory initiatives is conceptualised as the participants' ability to 'act on their own terms': to set agendas, gain recognition for their experiences and have a verifiable effect on policy or service development (Wilson and Beresford, 2000; Barnes and Prior, 2009). Domination, in turn, is understood as the administration's ability to 'steer the conversation': to determine what kind of participation is welcome, who are eligible as participants, what can be achieved through participation and which topics are to be discussed (Beresford, 2002; Cowden and Singh, 2007).

As some recent studies have begun to argue, this dichotomy might not be the most analytically robust way to approach the concept of power in participatory schemes (Pease, 2002). As Ganuza, Baiocchi and Summers $(2016,330)$ put it, 'there is always something potentially subversive, and unpredictable, in arrangements that imply 
[democratic] equality' (also Barnes, 2009b; Griggs et al., 2014). Conversely, Cressida Heyes's (2007) research shows that people may willingly choose to cultivate themselves in a way desired by the administration in an attempt to 'feel normal'. Subsequently, participatory initiatives should not simply be interpreted as either empowering or appropriating but instead the analytical gaze should be steered more towards the everyday practices where governing and resistance take shape.

The power to steer and limit, and to resist and subvert, especially in social policy contexts, becomes manifest in practices that determine concepts like 'normal behaviour', ‘useful participation' and ‘reliable knowledge’ (Barnes, 2008; Martin, 2012b; Miller and Rose, 2008). These practices operate through the participants' self-government, making their ways of being both a central target of governing and a tool of resistance (e.g. Randall and Munro, 2010; Dawney, 2011; Meriluoto, 2017). Subsequently, I draw on Foucault's analytical toolkit to shed light on power and resistance in the everyday practices and negotiations of the appropriate ways of being that take place within participatory arrangements.

\section{Struggles over ways of being - Foucault on power and}

\section{resistance}

Foucault argued that present-day forms of power operate through subjectivation - by influencing people's abilities and willingness to steer their own actions to construct themselves as subjects (Foucault, 2004, 108-113; also Kelly, 2009). More specifically, Foucault posited that the (Western) subject constructs themselves by 'getting to know themselves' and renders themselves governable by 'telling the truth about themselves' to others (Foucault, 2007). This makes definitions of knowledge and truth - or 'truth 
regimes' - key tools to steer the subject's way of being (Foucault, 2012; 1994; Cadman, 2010). Through them, it becomes possible to delineate what 'makes sense': what kind of making and representing of the self becomes feasible and rational and subsequently what kind of being is possible.

If power is exercised through attempts to define the possible forms of being, then resistance takes shape as a means to 'be differently' (Foucault, 2007; Death, 2016; Cadman, 2010). To illustrate this, Foucault chose the term counter-conduct (contreconduit) (esp. Foucault, 2004). By rejecting other possible concepts, such as resistance, Foucault wanted to underline the specificity of counter-conduct and its relation to power; governing as the conduct of conduct, and responding to this form of power through counter-conduct, were, for Foucault, interdependent and mutually constructive processes (Death, 2010; 2016; Haugaard, 2012; Medina, 2011).

Foucault described counter-conduct as 'the art of not being governed quite so much' (Foucault, 2007, 45), meaning that instead of referring to acts of 'pure' refusal, counter-conduct entailed more fine-tuned and subtle ways to work 'in line' with governing techniques (Death, 2016). As such, counter-conduct has the capacity to be creative, take initiative and produce something completely new (Binkley and Cruikshank, 2016; Cadman, 2010). As Cadman (ibid.) puts it, counter-conduct points towards the multitude of ways of 'being differently' that are not easily explained through a dichotomous view of self-government as either succumbing to the normalising process of self-making or refusing every aspect of such process as part of one's self. It takes place at the micro-scale, in everyday negotiations and subtle ways to be differently (also Death, $2010 ; 2016)$.

In this article, I employ the notion of parrhesia (parrêsia) as my analytical device to probe the interconnectedness of governing and resistance, assembled in ways of 
speaking 'truth to power' (Foucault, 2008; 2009; also Dyrberg, 2016; Davidson, 2011). The Greek concept of true speech, Foucault explains, refers to both the contents of truth, as well as a manner of telling the truth bluntly, frankly and risking everything (Foucault, $2008 ; 2009)$. As the 'counter discourse' of the subordinate, parrhesia is a prerequisite for any government to function legitimately. Its purpose is to point out the injustices performed by the government in order to make its uses of power appear logical, reasonable and fair (Foucault, 2008; also Dyrberg, 2016). Furthermore, as Luxon (2008) explains, parrhesiastic speech brings forth varied, personal truths, which challenge the dominant discourses or norms presented as self-evident (also Cadman, 2010).

Parrhesia is a particularly apt concept to illustrate both the position suggested for experts-by-experience by the projects' administration, as well as their means to contest and challenge it. As expertise-by-experience is a role crafted in order to bring forth 'raw, real-life experiences', parrhesia as a way of speaking the truth from 'below' (Foucault, 2008, 98) captures the expectations towards the experts'-by-experience subjectivity. Through the concept, it becomes possible to study what kind of knowledge and truth is expected (and accepted) from experts-by-experience and what kind of subjectivities are made possible for them in the process.

At the same time, parrhesia also entails subversive potential. Parrhesia, Foucault explains, signifies being adamantly and fearlessly connected to one's own perception of truth and purporting it at all costs (Foucault, 2008; Luxon, 2008). Consequently, it can be employed as a form of counter-conduct - as the freedom to think and act otherwise - by questioning the regime of truth through which people are engaged as objects and subjects of government (Cadman, 2010, 551; also Davidson, 2011; Death, 2016).

I use the notion of parrhesia to illustrate how knowledge, a certain manner of speaking, and the experts'-by-experience subjectivity are intertwined in the participatory 
initiatives practices of governing and resistance. As the experts-by-experience are both the objects of knowledge and agents of truth-telling (see Flynn, 1994, 106), their manner of speaking 'truth about themselves' is employable both as a means of governing their way of being, as well as a means of 'being differently' (also Collins, 2000). In the following, I will argue that the administration aims at harnessing the participants' critical discourses as a means to build up their legitimacy. By so doing, they also enable to interpret the notion of knowledge of the self differently. As a result, the participants employ 'unacceptable' forms of speech as their form of counter-conduct to challenge the subjectivity suggested upon them.

\section{Data and methodology - governmental ethnography of}

\section{resistance}

This article analyses expertise-by-experience in the context of the following, publically

funded projects:

1. Finnish Central Association for Mental Health: 'The establishment of expertiseby-experience and evaluation-by-experience in the development of mental health and substance abuse services'

2. The Federation of Mother and Child Homes and Shelters: 'Miina - The participation and empowerment of women who have encountered domestic violence'

3. No Fixed Abode: 'The utilisation of expertise-by-experience in the design and production of services for the homeless'

4. Muotiala Accommodation and Activity Centre Association: 'Turning experience into knowledge -project'

5. Sininauhaliitto ry: 'A low-threshold information and support centre for gambling problems'

6. City of Vantaa: 'Key to the Mind -project for developing mental health and substance abuse services in Southern Finland'

7. City of Tampere: 'SOS II - To Social Inclusion through Social Work'

The data analysed consists of themed interviews I conducted between 4.4.2014-

16.10.2015 with 23 experts-by-experience and 14 practitioners, a group discussion among 
five experts-by-experience organised on 30.11.2016 in of one of the projects studied and the projects' own as well as publically accessible documents on expertise-by-experience from the Ministry of Social Affairs and Health (MSAH) and the National Institute of Health and Welfare (THL).

My interpretations are also impacted by my experiences as a practitioner in one of the civil society organisations (CSOs) studied (see Mosse, 2006). During 2011-2014, I was in charge of developing expertise-by-experience in a CSO, and through the meetings and workshops organised I was a part of the concept's institutionalisation. I use notes, memos and co-produced material from this period as autoethnographic data to reflect on one process of expert-making where I myself was an active practitioner. I have retrospectively acquired written consent from my colleagues and experts-by-experience to use these data in my research. In order to closely follow the research ethical guidelines of the Finnish Advisory Board on Research Integrity (2009), I do not use excerpts from the ethnographic data in my analysis, taking into account the potential issues with retrospective consent (Tolich, 2010).

The experts-by-experience interviewed had suffered from domestic violence, substance abuse, mental health issues, homelessness, gambling or social exclusion in their past and had been invited to act in public and civil society organisations because of those experiences. Their tasks as experts were varied. Most commonly, they were performing 'gigs', as they called them; telling their stories to decision-makers and social welfare practitioners with an aim to 'broaden their view' or change their working methods. Often they also brought forward their experiential knowledge to develop better services, either within their home organisation, in service co-production networks, or in various committees tasked with re-drafting social policies at the national or municipal 
level. Many of the initiatives also entailed diverse experiments, such as art, discussion evenings or fieldtrips, to influence the local decision-makers directly and emotionally.

The projects, on their part, were all focused specifically on developing expertiseby-experience as a novel practice. This stemmed mostly from the demands and suggestions of their funders, the MSAH and The Slot Machine Association, which was a public gambling organisation whose profits went towards the funding of civil society organisations working in the health and social welfare sector. The purposes of expertiseby-experience were often inexplicit, and the most common stated purposes were 'advancing the participants' inclusion' and 'providing experiential knowledge to service co-production'. In many ways, expertise-by-experience resembles what Cornwall and Brock (2005) call a buzzword: an intrinsically good idea whose content and purpose is very little reflected upon.

To overcome the dichotomous setting between dominance and empowerment in my analysis, I follow the methodology of 'governmentality analysis with an ethnographic imaginary' (Brady and Lippert, 2016). Governmental ethnography takes a 'bottom up' approach to studying power and focuses on the techniques that a govermental rationality manifests itself through and the responses it invites (see also Foucault, 1982, 780). This allows to steer the analytical focus away from identifying who 'holds' power towards the more situated and everyday practices in which power is exercised, responded to and resisted (Foucault, 2007; 1982; also Lövbrand and Stripple, 2015; McKee, 2009). This provides a more nuanced view of power in participatory arrangements and highlights the salience of the negotiations and disputes that take place at the grassroots-level.

I have close-read my data using practices of counter conduct as my analytic lens. First, I identified the instances where my interviewees described friction between their actions and the expectations towards them. These included both their overt statements of 
deliberately 'doing differently' and also more subtle negotiations and suggestions where they had made an attempt to advance different ways of knowing and being to the official agenda. These practices of counter-conduct, then, allowed me to paint a picture of what they were resisting. This 'ideal way of being' for the experts-by-experience was rarely explicitly presented as a norm for the participants, but as the interviewees' descriptions will show us it narrowed their possibilities for being in practice. I term this way of being as governed parrhesia.

\section{Analysis: Uses and abuses of parrhesia}

\section{The parrhesiastic setting}

To illustrate how the stage was set for the experts-by-experience, I start with an extract from my field-notes. It recaps a discussion I had with two other civil society practitioners on the need for expertise-by-experience. During the conversation, which was organised to discuss my research themes, one of the practitioners described:

\footnotetext{
At some point, [social welfare] institutions start focusing on self-sustainment. This is also visible in patient organisations. The objective of expertise-by-experience is to renew civil society organisations' work and to bring their original purpose back to the centre. This is a corrective measure that brings the members' and the clients' voice back.
}

(a CSO practitioner, 10 April 2014, emphasis added)

A similar scenario was painted in a workshop organised by the THL on 22 January 2014. A public report of the event states:

Expertise-by-experience completes the administration's understanding, which can be detached from true everyday lives and practices. 
The underlying ethos of expertise-by-experience, then, seems quite ambitious: to provide decision-makers with the 'the raw and authentic truth' of the people, as they have drifted too far from the 'real' lives of citizens. Subsequently, this role of a truth-teller was what many experts-by-experience expected when engaging in the projects. They wanted to contest, shake and rattle 'the system' by incorporating their experiences into policymaking and service-production.

Peculiarly, however, when my interviewees recounted moments where they had 'caused a stir', they explained this behaviour to be problematic, unfitting and in conflict with what was expected of them. I will discuss these moments next.

\section{Parrhesia as counter-conduct}

The most reoccurring struggles between the participants' comportment and the expectations towards them concerned the criteria for appropriate speech and credible knowledge. The following public sector expert-by-experience gives us an example of speaking in a manner that 'intentionally pokes the hornets' nest':

E17: I know that sometimes, especially when I talk to the professionals, I intentionally poke the hornets' nest to evoke thoughts and emotions. But I warn them in advance. I think that professionals need to be able to hear all kinds of horrible things. I mean, they can't possibly work with customers if they can't be face to face with someone who says that they have been abused. I really do think that I need to have the right to say things the way they are. The way I see it, that's one important role I have.

The interviewee recognises how their frank speech does not fit easily with the expectations put upon them but chooses to speak bluntly anyway. They position expertsby-experience as those who dare to say and contest, and the more or less openly laid out suggestions for good expertise-by-experience provide them with a point of rebuttal. Here, 
it is precisely parrhesia that is made an integral part of expertise-by-experience - they are someone whose task it is to provide a contrasting point-of-view.

Speaking in ways that are considered 'unacceptable' or 'un-credible' was the participants means to contest the boundaries for acceptable speech and reliable knowledge (also Pease, 2002). The following civil society expert-by-experience provides us with another example. They recount an incident where they spoke in a manner that they assumed was not accepted but that they nonetheless considered a crucial part of who they want to be as an expert-by-experience:

E14: The last time I went there [to a steering group meeting], [a CSO] contacted me and asked if I could bring this one issue forward because they cannot. If they present it, this lady will end their contract, and they won't get their money. So I brought it up and it went okay, but I added some of my own perceptions to it. I said that this place of yours looks like a concentration camp, and that they had copied ideas from Hitler. The lady then announced that they no longer want to work with us.

TM: Right. What came out of it?

E14: Nothing. Everybody else was happy. And I managed to evoke a conversation there.

The above interviewee wants to construct themselves as precisely someone who pushes the boundaries and does unexpected things. They are someone who 'evokes conversation' and certainly does not shy away from confrontation, even provocation. Fearless speech gets presented as the very core of their experience-based action.

Many interviewees presented critical speech as their practice of freedom (see Griggs et al., 2014). As the following group discussant explains, it serves to ensure that the expert-by-experience 'is not exploited' and instead participates freely according to their own terms. Here, they illustrate how they will react to having been treated as a token in a project: 
G5: When I'll go there [to a seminar], I will be sure to give a speech that will be a slap in their faces. I will go and will deliver that speech, and I will say quite frankly what I think about this project. I mean, I won't trash the whole project, but I will give a speech that will surely make them tremble. We have to hold our own in those situations. I, for one, will not be exploited.

Parrhesia as speaking 'frankly' and 'making them tremble' pushes the boundaries of both the content and the manner of appropriate speech. Purporting the right to talk about what you want, the way you want, serves as a tool to contest the limits of possible action, but it is also a crucial component in the participants' self-construction. The following civil society expert-by-experience describes how their freedom from 'dictation' is a crucial foundation for their subjectivity as an expert-by-experience:

TM: Do you have any limits to what you can do as an expert-by-experience? Do you get any directions from [the organisation]?

E23: No. Once, a magazine wanted to interview me, and they [the project's employees] tried to hint that I should have talked to them before giving an interview. But I won't take that at all.

TM: Why not?

E23: This is my thing, and no one else needs to direct it. [... I I think that I should be allowed to say what I have on my mind and not have to polish it. It might be that in [a government organisation] there are these dignified gentlemen who can't bear to hear this. But I think that it's useless to speak if you can't say it the way you experience it.

For this interviewee, the possibility to speak their own truth to 'the dignified gentlemen of the state bureau' was their very reason for participating. All polished and compliant manners of speaking were 'useless', and authenticity was the very essence of experiencebased action.

The participants' counter-conduct also took the form of opening the doors to other people who did not meet the standards of 'appropriate participation'. The following civil 
society expert-by-experience explains how their position is to open up avenues for others' 'unwanted voices':

TM: Are the people you work with in [a Finnish town] also experts-by-experience? E6: Yes. They are in their own way because they live in these places. And what I try to accomplish there is that I go and pick also the voices that maybe are not so welcome otherwise. I mean precisely the negative stuff, what people actually say there.

The interviewee above also seeks to stretch the limits of appropriate speech and does so by appointing others as parrhesiastes and by doing so purports their right to be heard. Crucially, the experts-by-experience were not the only ones stretching the limits of acceptable forms of being, and the projects' practitioners are not the only ones 'steering the participants towards the normal'. Indeed, quite a few experts-by-experience, especially within the mental health sector, enforced the need for criteria defining 'a good participant' and embraced the subsequent hierarchy as a basis for their self-making. On the other hand, some practitioners explicitly stated wanting to challenge the notion of 'normal' and 'acceptable' in the projects' context, claiming a subversive position towards the projects' official goals, as does the following civil society practitioner:

P13: At this point, it is probably good to tell you that I'm somewhat sceptical of the model [of expertise-by-experience]. I wonder whether the heavy training demands result in a setting where people's experiences are validated through a training that is planned and conducted by professional experts. I mean, that it is only after [the training] that they get a say and the freedom to speak in matters where they should be listened to anyway.

The practitioner above overtly criticises the demands made for the experts-by-experience and later during the interview explains how they have wanted to do things 'differently'. Hence, the dichotomous setting between the administration that attempts to govern and limit and the participants that either resist or succumb appears problematic. 
The techniques of counter-conduct illustrated above can all be seen as means to take part in defining what kind of participation should be feasible and accepted. Counterconduct - acting against the norm of a good participant - is one way to illuminate and push the boundaries of feasible action without renouncing from the participatory scheme altogether. The wild and uncontrolled speech is also the participants' way of constructing alternative subjectivities for themselves that are based on the freedom to voice out criticism. It is a means not to succumb to the role suggested upon them by the administration, which the participants perceive as being too narrow and constraining.

These practices of counter-conduct were more common in a civil society context. In the public sector, more experts-by-experience expressed content with their role and had internalised its demands for their way of being. When asked about their motivations for participation, public sector experts-by-experience tended to emphasise the will to help others by developing services with professionals, whereas experts-by-experience in CSOs also described 'urges' to 'break taboos' or to have a political impact. Furthermore, experts-by-experience with a mental health background were less subversive than other participants. I have argued elsewhere that these differences can stem from different justification regimes drawn upon when developing expertise-by-experience (Meriluoto, 2018). On the other hand, they can also be illustrative of the hierarchical power dynamics in the psychiatric domain, enticing the experts-by-experience to 'heal' according to the instructions suggested to them (Randall and Munro, 2010). Obviously, these categorisations are not clear-cut, and significant exceptions occur.

\section{What is resisted? - Governed parrhesia}

Based on the above practices of counter-conduct, it is possible to discern the elements of the often-inexplicit ideal subjectivity towards which the participants are being conducted. 
The uninhibited speech was the participants' way of countering the projects' two main governing strategies. First, it was a means to challenge the position of someone 'in need of empowering', which legitimised the techniques directed at steering the participants' way of being. Parrhesia was a manner of building up subversive subjectivities that decidedly were not in need of any guidance of steering but on the contrary were very much founded on independent truth-telling. The following civil society expert-byexperience describes how they felt like 'empowerment' was an attempt to undermine and take control over their way of being:

E17: For a long time I had a feeling that I definitely didn't belong there [in a training for experts-by-experience]. There was this one time when a professional said to me something like, 'Listen, this is rehabilitation. This is meant for people who are only just recovering.' I got a feeling that she tried to force me into the role of someone who is recovering, which I didn't feel like being anymore. [...] I was pushed down by saying 'hey, you're recovering'. I got a feeling that [with a patronising voice], 'Were now trying to nurse and empower you, don't you try to be too active yet. Just take it easy.'

In the interviewee's narrative, empowerment becomes the tool through which the practitioners steer the participants' self-making (also Cruikshank, 1999; Miller and Rose, 2008; O'Toole and Gale, 2014). Furthermore, they interpret the 'empowerment' practices as belittling; as attempts to position them as someone in need of nurturing and caring and not capable of initiating change themselves (Eliasoph, 2016; Green, 2000; Julkunen and Heikkilä, 2007). This criticism is analogous with the feminist critique of empowerment and acclaims how empowerment cannot be 'done to others' but rather has to rise from among the subordinate groups themselves (Collins, 2000; McLaughlin, 2014). As a case in point, the above interviewee detaches themselves from the empowerment scheme and instead constructs themselves as an active figure, who relies on their own ways of telling who they are. 
Second, the rough, even provocative way of speaking was the participants' way of questioning the neutral and co-operative discourse expected of them. The following quote from a public sector expert-by-experience illustrates how they have internalised certain preconditions of a good expert-by-experience. In their view, the ability to use 'diplomatic' vocabulary and to work towards a common good are both prerequisites for experts'-by-experience participation, as well as being signs of recovery:

E11: I also think that it [expertise-by-experience] requires diplomacy. I mean that you can look at things from many different angles because it is useless if you just go there and shake your fist that this has gone to hell. You have to be able to suggest a solution. It doesn't promote the customers' status in any way if you are very offensive and rude about how bad things are in Finland.

A possible way of speaking for an expert-by-experience is, hence, not an aggressive promotion of their own agenda. On the contrary, in order for expertise-by-experience to be accepted as expertise, participation needs to be a co-operative and consensus-seeking activity, appreciating and conforming to the administration's ideal of correct conduct (also Martin, 2012b; 2009; Beresford, 2002; Eliasoph, 2014). Prior research suggests this to be symptomatic of the network-governance project, which seeks to constructs citizens as partners, who are working in collaboration towards mutual goals, and to supress conflict (Lee et al., 2015; Newman and Clarke, 2009). The following civil society expertby-experience affirms this:

E13: When you encounter people who work in the administration, they're always doubtful as to whether or not you already possess enough knowledge to be on the same level with them. Like, 'are we on the same level, or are you still there in the resistance'? I mean, are you someone who has only come here to complain and who will take off as soon as you feel better, or are you also on our side?

By operating on definitions of knowledge, the projects attempt to construct a neutral and 
co-operative manner of speaking as a sign of 'recovery'. This constructs vocal resistance as a sign of 'not quite being ready' for participation. The failure to uphold to these prerequisites, consequently, will easily lead to exclusion from participation altogether, as the following group discussant forcefully puts:

\footnotetext{
G4: They tell you what the topic of your talk will be and what opinion you should hold. If you don't agree, then you don't need to come at all. [...] I mean, they say that you can disagree with the professionals, but you have to remain within a certain frame. So, in effect, you can slightly disagree, but if you disagree a lot, it is a wrong opinion to have.
}

The object of resistance appears as a form of participation that I call governed parrhesia. It is a manner of presenting the experts'-by-experience role as one of 'speaking truth to power' but in many subtle ways steering and limiting what is considered to be 'the truth' in this context. By defining rather strict criteria for the experts'-by-experience 'credible discourse', it becomes possible to delegitimise and ignore 'too wild' and 'too raw' experiences. As the participants of a THL workshop on 22 January 2014 colourfully put it, these demands made the experts-by-experience 'lose their edge and their rock'n roll' and become 'poodles that are paraded around'.

As McLaughlin (2014) explains, allowing participation to a limited extent but within narrow parameters may give the participants an illusion of power while actually solidifying the existing power dynamics (also Blühdorn, 2013). Consequently, the experts'-by-experience participation may serve to legitimise the administration's decisions by showing how they have upheld the requirement of civic engagement without truly contesting their understanding of what constitutes expertise and what should be regarded as valuable knowledge in this context.

This interpretation gains support from the lack of experiences of 'true impact' among the experts-by-experience. When inquiring about the perceived impact of their 
actions, some interviewees believed that they were able to influence the perceptions and attitudes of individual practitioners and decision-makers. However, many experts-byexperience used words like frustration and mascot when describing their experiences of influencing decision-making. Although some individual practitioners and politicians as a group discussant put it 'were genuinely interested in listening', according to a disappointed expert-by-experience from a CSO, the experts'-by-experience participation 'leads nowhere' on a larger scale. The instances where the experts'-by-experience critical way of being resulted in anything more than a performative illumination of the unjust boundaries for their way of being were close to non-existent. Furthermore, some interviewees stated that they never expected their participation to have any broader, societal impact and were instead content with the experiential aspect of participation (see Leemann and Hämäläinen, 2016). These interviewees felt empowered and included even without any evidence of the impact of their actions.

\section{Conclusions}

In this article, I have explored the interplay of governing and resistance in participatory arrangements, which are assembled in ways of speaking truth to power. I have illustrated how the administrations of projects developing expertise-by-experience have taken up the parrhestiastic ethos as a tool to legitimise their rule. The service users were invited to the projects as 'truth-tellers' whose task was to bring 'raw experiences' into decision-making. However, as the participants' forms of counter-conduct show, the participants largely view this position as a form of 'governed resistance' that only allows critique up to a certain point.

Furthermore, I have illustrated how the governing practices invite various creative, grassroots-level practices of counter-conduct that engage with the governing 
practices in order to alter them. By taking up the initiatives' promise of treating them as 'truth-tellers', the participants illuminate and contest the boundaries of what can and should be considered 'knowledge' in the initiatives. Through parrhesiastic speech, the participants strengthen their connection to their own version of the truth and exemplify the primacy of their experiential knowledge as a basis for their subject-construction. Parrhesia, then, serves as their means of being (conceived of) otherwise and as a tool to politicise knowledge in the projects' context.

These interpretations illustrate the situatedness and interconnectedness of practices of governing and resistance in participatory arrangements. First, as it was often experts-by-experience who sought to define criteria for correct comportment, and reversely, practitioners who sought to destabilise existing understandings of knowledge, the ladder-based models used to illustrate the democratic capacity of participatory initiatives appears problematic. Instead of attempting a diagnostic on the extent to which power is 'given' to the participants, the analytical focus should be on situated practices and everyday negotiations on the conditions of ways of being where power actualises.

Second, although the participants' critical speech challenges certain aspects of the projects, it also strengthens their underlying ethos of participatory governance. By engaging in negotiations about who should be allowed to participate, the participants reinforce the objective of increased participation and employ its discourse as tools in their own formulations on different ways of being. By using parrhesia, they highlight the necessity of including subaltern voices to legitimise government and hence reinforce the participatory governance ethos of enticing participation to accumulate different forms of knowledge as a basis for political decision-making.

In sum, expertise-by-experience is a good illustration of governing and resistance being mutually dependent forms of power. On the one hand, the projects' administration 
need the participants' free, critical truth-telling to legitimise their administrative power.

On the other hand, the administrations' attempts to harness the participants critique to serve only the purposes that best suit the administration provide the participants a point of rebuttal on which they can construct their alternative way of being. This view might open up another manner of looking at the governmentality of empowerment projects. It allows to perceive how the projects might in fact serve as 'empowering', i.e. opening up ways for the participants to construct themselves 'freely' precisely because of their attempts to define the participants' way of being. By providing the participants something to subvert, the projects may (inadvertently) provide their participants a basis for counter-conductive self-making.

However, while their critical way of being makes the existing boundaries of legitimate participation visible, thus enabling their critique, little evidence exists of transformations in the dominant paradigm of knowledge as a result of this critique. The participants may indeed be capable of carving out ways to construct themselves freely, but effects that go beyond individual experiences of subversive self-making and performative illuminations of the unjust boundaries of participation, are scarce. This observation points to the limitations of a Foucauldian approach, prompting further studies on the effects and limits of participants' critique. 


\section{References}

Arnstein SR (1969) A ladder of Citizen participation. Journal of the American Institute of Planners 35(4): 216-224.

Baistow K (1994) Liberation and regulation? Some paradoxes of empowerment. Critical Social Policy 14(42): 34-46.

Barnes M (2009a) Authoritative Consumers or Experts by Experience? User Groups in Health and Social Care. In: Simmons R, Powell M and Greener I (eds) The Consumer in Public Services: Choice, Values and Difference. Bristol: Policy Press, 219-234.

Barnes M (2009b) Alliances, contention and oppositional consciousness: can public participation generate subversion? In: Barnes M and Prior D (eds) Subversive Citizens: Power, Agency and Resistance in Public Services. Bristol: Policy Press, 33-48.

Barnes M (2008) Passionate participation: Emotional experiences and expressions in deliberative forums. Critical Social Policy 28(4): 461-481.

Barnes M and Prior D (2009) Subversive Citizens: Power Agency and Resistance in Public Services. Bristol: Policy Press.

Beresford P (2002) User Involvement in Research and Evaluation: Liberation or Regulation? Social Policy and Society 1(2): 95-105.

Binkley S and Cruikshank B (2016) Counter-Conduct Introduction . Foucault Studies 21: 3-6.

Blühdorn I (2013) The governance of unsustainability: ecology and democracy after the postdemocratic turn. Environmental Politics 22(1): 16-36.

Brady M and Lippert RK (2016) Governing Practices: Neoliberalism, Governmentality and the Ethnographic Imaginary. Toronto: University of Toronto Press.

Cadman L (2010) How (not) to be governed: Foucault, critique, and the political . Environment and Planning D: Society and Space 28(3): 539-556.

Collins PH (2000) Black Feminist Thought: Knowledge, Consciousness, and the Politics of Empowerment. New York: Routledge.

Cornwall A and Brock K (2005) What do buzzwords do for development policy? a critical look at 'participation', 'empowerment' and 'poverty reduction'. Third World Quarterly 26(7): 1043-1060.

Cowden S and Singh G (2007) The 'User': Friend, foe or fetish?: A critical exploration of user involvement in health and social care. Critical Social Policy 27(1): 5-23.

Cruikshank B (1999) The Will to Empower. Democratic Citizens and Other Subjects.\&nbsp; Ithaca: Cornell University Press.

Davidson AI (2011) In praise of counter-conduct. History of the Human Sciences 24(4): 25-41.

Dawney L (2011) Social imaginaries and therapeutic self-work: the ethics of the embodied imagination. The Sociological Review 59(3): 535-552.

Death C (2016) Counter-Conducts as a Mode of Resistance: Ways of "Not Being Like That" in South Africa. Global Society 30(2): 201-217. 
Death C (2010) Counter-conducts: A Foucauldian Analytics of Protest. Social Movement Studies 9(3): 235-251.

Dyrberg TB (2016) Foucault on parrhesia: The Autonomy of Politics and Democracy. Political Theory 44(2): 265-288.

Eliasoph N (2016) The mantra of empowerment talk: an essay. Journal of Civil Society 12(3): 247265.

Eliasoph N (2014) Measuring the Grassroots: Puzzles of Cultivating the Grassroots from the Top Down. The Sociological Quarterly 55(3): 467-492.

Finnish Advisory Board on Research Integrity (2009) Ethical Principles of Research in the Humanities and Social and Behavioural Sciences and Proposals for Ethical Review. Helsinki: National Advisory Board on Research Ethics.

Flynn T (1994) Foucault as parrhesiast: His last course at the Collège de France (1984)\&nbsp; In: Bernauer J and Rasmussen D (eds) The Final Foucault. Cambridge: The MIT Press, 102-118.

Foucault M (2012) Du Gouvernement Des Vivants. Cours Au Collège De France 1979-1980. Paris: Gallimard Seuil.

Foucault M (2009) Le Courage De La Vérité. Le Gouvernement De Soi Et Des Autres II. Cours Au Collège De France 1984. Paris: Gallimard Seuil.

Foucault M (2008) Le Gouvernement De Soi Et Des Autres. Cours Au Collège De France 1982- 1983. Paris: Gallimard Seuil.

Foucault M (2007) The Politics of Truth. Los Angeles: Semiotext(e).

Foucault M (2004) Sécurité, Territoire, Population. Cours Au Collège De France 1977-1978. Paris: Gallimard Seuil.

Foucault M (1994) Dits Et Écrtis IV (1980-1988). Paris: Gallimard.

Foucault M (1982) The Subject and Power. Critical Inquiry 8(4): 777-795.

Fox NJ, Ward KJ and O'Rourke AJ (2005) The 'expert patient': empowerment or medical dominance? The case of weight loss, pharmaceutical drugs and the Internet. Social Science \& Medicine 60(6): 1299-1309.

Ganuza E, Baiocchi G and Summers N (2016) Conflicts and paradoxes in the rhetoric of participation. Journal of Civil Society 12(3): 328-343.

Green M (2000) Participatory Development and the Appropriation of Agency in Southern Tanzania. Critique of Anthropology 20(1): 67-89.

Griggs S, Norval AJ and Wagenaar H (2014) Practices of Freedom : Decentred Governance, Conflict and Democratic Participation. Cambridge: Cambridge University Press.

Haugaard M (2012) Rethinking the four dimensions of power: domination and empowerment. Journal of Political Power 5(1): 33-54.

Heyes CJ (2007) Self-Transformations: Foucault, Ethics and Normalized Bodies. Oxford: Oxford University Press. 
Julkunen I and Heikkilä M (2007) User involvement in personal social services. In: Berkel R and Valkenburg B (eds) Making it Personal. Individualising Activation Services in the EU. Bristol: Policy Press.

Kelly MGE (2009) The Political Philosophy of Michel Foucault. New York: Routledge.

Lee CW, McQuarrie M and Walker E, T. (2015) Democratizing Inequalities: Dilemmas of the New Public Participation. New York: NYU Press.

Leemann L and Hämäläinen R (2016) Asiakasosallisuus, sosiaalinen osallisuus ja matalan kynnyksen palvelut. Yhteiskuntapolitiikka 81(5): 586-594.

Leppo A and Perälä R (2009) User involvement in Finland: the hybrid of control and emancipation. Journal of Health Organization and Management 23(3): 359-371.

Lövbrand E and Stripple J (2015) Foucault and critical policy studies. In: Fischer F, Torgerson D, Durnová A and Orsini M (eds) Handbook of Critical Policy Studies. Cheltenham: Edward Elgar, 92108.

Luxon N (2008) Ethics and Subjectivity: Practices of Self-Governance in the Late Lectures of Michel Foucault. Political Theory 36(3): 377-402.

Martin GP (2012a) Service users and the third sector: opportunities, challenges and potentials in influencing the governance of public services. In: Barnes M and Cotterell $\mathrm{P}$ (eds) Critical Perspectives on User Involvement. Bristol: Policy Press, 47-55.

Martin GP (2012b) Public deliberation in action: Emotion, inclusion and exclusion in participatory decision making. Critical Social Policy 32(2): 163-183.

Martin GP (2009) Public and User Participation in Public Service Delivery: Tensions in Policy and Practice. Sociology Compass 3(2): 310-326.

Matthies A (2017) Osallistumisen lupaus ja petos hyvinvointipalveluissa. Sosiologia 54(2): 149-165.

Matthies A, Närhi K and Kokkonen T (2018) Promise and Deception of Participation: Janus-faces of Welfare Services for Unemployed Young People. Critical Social Work.

McKee K (2009) Post-Foucauldian governmentality: What does it offer critical social policy analysis? Critical Social Policy 29(3): 465-486.

McKee K and Cooper V (2008) The Paradox of Tenant Empowerment: Regulatory and Liberatory Possibilities. Housing, Theory and Society 25(2): 132-146.

McLaughlin K (2014) Empowering the people: 'empowerment' and the British Journal of Social Work, 1971-99. Critical and Radical Social Work 2(2): 203.

Medina J (2011) Toward a Foucaultian Epistemology of Resistance: Counter-Memory, Epistemic Friction and Guerrilla Pluralism. Foucault Studies 12: 9-35.

Meriluoto T (2018) Neutral Experts or Passionate Participants? - Renegotiating Expertise and the Right to Act in Finnish Participatory Social Policy. European Journal of Cultural and Political Sociology.

Meriluoto T (2017) Turning Experience into Expertise: Technologies of the Self in Finnish Participatory Social Policy. Critical Policy Studies.

Meriluoto T (2016) Kokemusasiantuntijuus ohjaavana ja voimaannuttavana hallintana. In: Nousiainen M and Kulovaara K (eds) Hallinnan Ja Osallistamisen Politiikat. Jyväskylä: SoPhi, 65-96. 
Miller P and Rose N (2008) Governing the Present: Administering Economic, Social and Personal Life. Cambridge: Polity Press.

Mosse D (2006) Anti-Social Anthropology? Objectivity, Objection, and the Ethnography of Public Policy and Professional Communities. The Journal of the Royal Anthropological Institute 12(4): 935956.

Närhi K and Kokkonen T (2014) Transformation of participation politics and social citizenship in Finnish welfare governance. In: Matthies A and Uggerhoej L (eds) Participation, Marginalization and Welfare Services : Concepts, Politics and Practices Across European Countries. Surrey: Ashgate, 95112.

Newman J and Clarke J (2009) Publics, Politics and Power : Remaking the Public in Public Services. London: SAGE Publications.

Noorani T (2013) Service user involvement, authority and the 'expert-by-experience' in mental health. Journal of Political Power 6(1): 49-68.

O'Toole T and Gale R (2014) Participatory Governance in Practice. In: Anonymous Practices of Freedom. Cambridge: Cambridge University Press, 199-216.

Papadopoulos Y and Warin P (2007) Are innovative, participatory and deliberative procedures in policy making democratic and effective? European Journal of Political Research 46(4): 445-472.

Pease B (2002) Rethinking empowerment: a postmodern reappraisal for emancipatory practice. Britisj Journal of Social Work 32(2): 135-147.

Polletta F (2014) Is Participation Without Power Good Enough? Introduction to "Democracy Now: Ethnographies of Contemporary Participation”. The Sociological Quarterly 55(3): 453-466.

Prior D (2009) Policy, power and the potential for counter-agency. In: Barnes M and Prior D (eds) Subversive Citizens. Power, Agency and Resistance in Public Services. Bristol: Policy Press, 17-32.

Randall J and Munro I (2010) Foucault's Care of the Self: A Case from Mental Health Work. Organization Studies 31(11): 1485-1504.

Rissanen P (2015) Toivoton Tapaus? Autoetnografia Sairastumisesta Ja Kuntoutumisesta. Helsinki: Kuntoutussäätiö.

Tolich M (2010) A Critique of Current Practice: Ten Foundational Guidelines for Autoethnographers. Qualitative Health Research 20(12): 1599-1610.

Warren ME (2009) Governance-driven democratization. Critical Policy Studies 3(1): 3-13.

Wilson A and Beresford P (2000) 'Anti-oppressive practice': emancipation or appropriation? British Journal of Social Work 30(5): 553-573. 
This work was supported by the Academy of Finland under the project Superdemocracy - A Critical Assessment of the Participatory Turn, grant No. 21000024131. 